There are excellent chapters on the history and present state of coal-mining and a good summary of Svalbard's political history, with an interesting note on events in Svalbard between 1940 and 1945.

On exploration there are two chapters, one covering discovery and whaling up to about 1800 , the other covering later scientific work. The second is largely a summary of activity after 1800 and there is regrettably little information about expeditions after 1900 with the exception of Norwegian work. G. Binney and A. R. Glen are mentioned in passing, but the long series of Oxford and Cambridge expeditions between the two world wars receive little notice. Some expeditions are omitted in the general chapters on exploration but are mentioned later in the book. Thus a short account of the misfortunes of the Schröder-Stranz expedition, 1912-13, appears in a section dealing with the author's own visit to the Sorgfjorden area.

This haphazard manner of handling the material is the main weakness of the book, especially as no index is provided. It is to be hoped that this omission will be rectified in the next edition, as it cannot fail to enhance the usefulness of the book.

The second section is similar in style to Ingstad's other books, such as $\phi$ st for den store bre (Oslo, 1935), well-written with plenty of interesting detail. Ingstad travelled widely in Spitsbergen and used his own dog team, brought from East Greenland in 1933. On several occasions he made journeys up into the inland areas of Vestspitsbergen and travelled over Ny Friesland, visiting isolated trappers and Russian mines. The book ends with an account of his last visit in 1947; he describes the effects of the war, especially the damage caused by the German naval attack on Longyearbyen in 1944. There are two excellent maps and a useful and up-to-date list of references; furthermore there is a fine selection of illustrations.

Last year Norway celebrated its twenty-fifth year of sovereignty in Svalbard. Although this book appeared two years earlier, it was well-timed. Notwithstanding certain inconsistencies, it is an eminently readable account of Svalbard to-day, with a useful survey of the historical and geographical background.

J. G. ELBO

\title{
ADMINISTRATION OF HEARD ISLAND AND THE MCDONALD ISLANDS
}

[The following statement was issued by the Commonwealth Relations Office on 8 February 1951. An account of the establishment of an Australian meteorological station on Heard Island in 1947 was given in the Polar Record, Vol. 5, Nos. 37/38, 1940, p. 317-23.]

"The Australian Government took over the administration of Heard Island and the McDonald Islands in December 1947, by agreement with the United Kingdom Government. The transfer of the islands was confirmed by an exchange of letters between the two Governments on 19 December 1950. With the agreement of the Australian Government these letters are now published. Heard Island is in lat. $53^{\circ} \mathrm{S}$., long. $75^{\circ} \mathrm{E}$., and the McDonald Islands are in lat. $53^{\circ} \mathrm{S}$., long. $72^{\circ} \mathrm{E} . "$ 


\section{Letter dated 19 December 1950, from the Resident Minister for Australia in London to the Secretary of State for Commonzealth Relations}

My dear Secretary of State,

I have the honour to refer to the letter from the Office of the United Kingdom High Commissioner in the Commonwealth of Australia, dated 23 December 1947, in which His Majesty's Government in the United Kingdom confirmed their willingness to transfer to His Majesty's Government in the Commonwealth of Australia their rights in Heard Island and McDonald Islands.

In consequence of this communication, effective government, administration and control of these islands were established by the Commonwealth Government on 26 December 1947.

Accordingly, the Commonwealth Government for their part understand the position to be that as from that date His Majesty's sovereignty over these islands has been exercised by them and the rights of the United Kingdom Government in the islands have been transferred to them and that, by such transfer and by the establishment of effective Australian government, administration and control, the territory has been acquired by the Commonwealth. The Commonwealth Government would be grateful to learn whether this is also the understanding of His Majesty's Government in the United Kingdom.

Yours sincerely,

[Signed] Eric J. Harrison

\section{Letter dated 19 December 1950, from the Secretary of State for Commonwealth} Relations to the Resident Minister for Australia in London

My dear Resident Minister,

I have the honour to acknowledge receipt of your Note of 19 December 1950 on the subject of Heard and McDonald Islands.

In reply, I have to inform you that for their part His Majesty's Government in the United Kingdom regard His Majesty's sovereignty in these islands as having been exercised by and their own rights as having been transferred to His Majesty's Government in the Commonwealth of Australia and the territory as having been acquired by the Commonwealth by such transfer and by the establishment of effective Australian government, administration and control, as from 26 December 1947.

Yours sincerely,

[Signed] P. C. GoRDON-WALEER

\section{ADMINISTRATION OF THE PRINCE EDWARD ISLANDS}

[The following statement was issued by the Commonwealth Relations Office on 8 September 1950. The text of a South African Proclamation on these islands, dated 24 January 1948, was given in the Polar Record, Vol. 5, Nos. 35/36, 1948, p. 243-44. An account of the establishment of a South African meteorological station on Marion Island was given in the Polar Record, Vol. 5, No. 40, 1950, p. 576-79.]

"The South African Government took over the administration of Marion and Prince Edward Islands at the end of 1947, by agreement with the United King-

1 The omission in Mr Gordon-Walker's letter represented by dots recapitulates the substance of the letter from Mr Harrison given above. 